\title{
Shadow Banking, Monetary Policy, and Confidence Effects in China: Empirical Research Using a Structural Vector Autoregressive Model
}

\author{
He Cong \\ Institute of Economics, School of Social Sciences, Tsinghua University, Beijing, China \\ Email: thuconghe@163.com, chenyangrw07@163.com
}

How to cite this paper: Cong, H. (2019) Shadow Banking, Monetary Policy, and Confidence Effects in China: Empirical Research Using a Structural Vector Autoregressive Model. Modern Economy, 10, 1-11.

https://doi.org/10.4236/me.2019.101001

Received: October 29, 2018

Accepted: January 7, 2019

Published: January 10, 2019

Copyright $\odot 2019$ by author(s) and Scientific Research Publishing Inc. This work is licensed under the Creative Commons Attribution International License (CC BY 4.0).

http://creativecommons.org/licenses/by/4.0/

\begin{abstract}
By using monthly data regarding the scale of shadow banking, interest rates, loan balances, and the market confidence index in China from 2013 to 2017, this study constructed a structural vector autoregressive model to investigate the impacts of monetary policies and confidence in the economy with a special parallel financial intermediary. The regression results indicated that the tightening of monetary policy had compressive effects on commercial banks and shadow banking in China; however, the characteristics of Chinese shadow banking increased overall economic volatility, making the financial system more vulnerable. In addition, this study determined that the influence of confidence in the market in China, as demonstrated through responses of monetary policy authorities, had a considerable effect on shadow banking. We further determined the channel through which confidence affected the credit scale.
\end{abstract}

\section{Keywords}

Shadow Banking, Monetary Policy, Confidence Effect, Structural Vector Autoregressive Model

\section{Introduction}

Shadow banking has become considerably more prevalent over the preceding decade in China and has raised the potential systemic risks of the Chinese financial market. Essentially, shadow banking in China constitutes investments made by commercial banks that are kept off banks' balance sheets to evade loan restrictions. This differs from the nature of shadow banking in the United States. According to Adrian and Shin [1], Gorton and Metrick [2], and Pozsar, Adrian, 
Ashcraft, and Boesky [3], the typical shadow banking products available in developed economies are asset-backed commercial securities, money market funds, and other innovative financial tools. Chinese banks conducting shadow banking mostly use entrusted loans and trust loans as their investment instruments. As argued by Wang et al., two features distinguish shadow banking in China from that in the West: 1) shadow banking in China is dominated by traditional commercial banks, and 2) shadow banking is implicitly endorsed by the Chinese government [4]. In addition, more than half of the business flow of shadow banking in China is essentially that of "bank loans in disguise" [5].

The aforementioned differences between shadow banking in China versus that in the West can be explained in terms of economic transition in China. Market reform in China has led to a dual-track economic system of state-owned enterprises (SOEs) and non-SOEs. A lack of credit support for non-SOEs has stimulated the demand for shadow banking. As argued by Elliott et al., banks in China have failed to fully serve non-SOEs, especially small- and medium-sized enterprises in the private sector [6]. Conversely, the direct financing market in China remains underdeveloped. Commercial banks are restricted to providing loans for high-return enterprises; as a result, banks have had a strong incentive to evade loan controls through shadow banking, and consequently, shadow banking has emerged and become more prevalent in China.

Fiscal and monetary policy has also facilitated shadow banking in China. To cope with the global financial crisis in 2008, the Chinese government launched a RMB 4 trillion stimulus plan coupled with a low interest rate policy, and numerous credit funds were funneled through local government financing platforms into infrastructure and real estate projects. Ever since, economic optimism and incidence of some speculative behaviors have increased sharply. To prevent the economy from overheating, the government began to tighten monetary policy in late 2010; however, this did not alter societal expectations concerning the market. Prosperity attributable to economic fundamentals instilled confidence in market participants, and the tightening of monetary and credit policies failed to compress market leverage. By contrast, financial institutions were enabled to bypass regulations by cooperating with trust companies, asset management companies, and other institutions in providing considerable credit support to business entities in a manner that kept such activity off the banking system's official balance sheets. It was during this period that China's shadow banking system expanded exponentially.

When shadow banking prospers, the efficacy of monetary policy is drops and the dependency of financial stability on market confidence increases; this is because banks conducting shadow banking cannot acquire liquidity support from the monetary authority and are thus prone to bank runs. Zhu analyzed the development of shadow banking in China from the historical perspective [7]. Ehlers et al. summarized the characteristics and structure of Chinese shadow banking [8]. Verona et al. [9] and Funke et al. [10] have developed theoretical 
models to investigate the confidence effect in economies and have indicated that the efficiency of monetary policy is dependent on sources of economic shocks. A growing number of studies have focused on empirical analysis; Allen et al. performed transaction-level analyses of entrusted loans and reported various motives for multiple types of entrusted loans [11]. Chen et al. discovered that commercial banks and shadow banks respond to monetary policy in opposite manners, suggesting that shadow banking in China weakens the effectiveness of monetary policy [12].

Research focusing on confidence effects lacks empirical support, and most empirical studies have used entrusted loans and other off-balance-sheet products as proxies for shadow banking in China because the scale of shadow banking is relatively difficult to measure. The present study employed an implicit method for measuring the scale of shadow banking in China rather than using a single financial product as a proxy. We analyzed the interrelationships between shadow banking, monetary policy, and the confidence effect by using the structural vector autoregressive (SVAR) model. This paper aims to shed light on the channel through which shadow banking and commercial banks respond to changes in confidence. The regression results indicated that confidence affects the economy through the interest rate, which reveals feedback of the monetary authority to market prosperity.

The remainder of this article is organized as follows. Section 2 presents the measurement of the scale of China's shadow banking. Section 3 describes the construction and results of the SVAR model. Finally, Section 4 presents the conclusions and policy implications of this study.

\section{Measurement of the Scale of China's Shadow Banking and Market Confidence}

China's shadow banking system is different from that of the United States, where use of asset securitization products is most prominent of any country worldwide. The shadow banking in China is closely related to commercial banks; it could even be said that China's shadow banks are institutions that both depend on commercial banks and help such banks to circumvent regulations.

Because of the diversity of banking business models, complexity of the accounting subjects involved, and variety of participating institutions, direct calculation of the scale of shadow banking in China is difficult. This study used the method of Sun and Jia [13], which entails starting from the basic accounting principle of "credit equals debt" and then deducting all "nonshadow assets"- such as loans, foreign exchange, corporate bonds, and other traditional assets-from the total liabilities to obtain the scale of shadow banking. This method can be represented as follows:

$$
\mathrm{NSB}+\mathrm{SB}=\mathrm{L}+\mathrm{FE}+\mathrm{EB}+\mathrm{SB}=\mathrm{D},
$$

where NSB is "nonshadow assets," SB is "shadow assets," L is loans, FE is funds outstanding for foreign exchange, EB is corporate bonds, and D is deposits. 
$\mathrm{D}$ comprises various sources and can be represented as follows:

$$
\mathrm{D}=\mathrm{DR}+\mathrm{DC}+\mathrm{C}+\mathrm{DG}+\mathrm{DNB}+\mathrm{K},
$$

where DR is deposits of residents, DC is deposits of nonfinancial corporations, C is currency in circulation, DG is governmental deposits, DNB is interbank deposits of nonbank financial institutions, and $\mathrm{K}$ is the net assets of all banking financial institutions.

DG also comprises various sources and can be expressed as follows:

$$
\mathrm{DG}=\mathrm{DGB}+\mathrm{DGC}-\mathrm{TBB}-\mathrm{TBC},
$$

where DGB is deposits of the government in commercial banks, DGC is deposits of the government in the central bank, TBB is treasury bonds held by commercial banks, and TBC is treasury bonds held by the central bank.

An additional equation can be derived from Equation (1) and Equation (2) to account for the effect of off-balance-sheet wealth management products:

$$
\begin{aligned}
\mathrm{SB}= & (\mathrm{DR}+\mathrm{DC}+\mathrm{C}+\mathrm{DNB})+\mathrm{DG}+\mathrm{K}+\mathrm{FM}-(\mathrm{L}+\mathrm{FE}+\mathrm{EB}) \\
= & \mathrm{M} 2+\mathrm{DG}+\mathrm{K}+\mathrm{FM}-(\mathrm{L}+\mathrm{FE}+\mathrm{EB}) \\
= & \mathrm{M} 2+(\mathrm{DGB}+\mathrm{DGC}-\mathrm{TBB}-\mathrm{TBC})+\mathrm{K} \\
& +\mathrm{FM}-(\mathrm{L}+\mathrm{FE}+\mathrm{EB}),
\end{aligned}
$$

where M2 is money and quasimoney and FM is off-balance-sheet wealth management products.

By using these equations, the scale of China's shadow banking from 2013 to 2017was obtained and is graphically represented in Figure 1.

In our model, market confidence was measured using the Purchasing Managers' Index (PMI), which is an appropriate proxy for confidence level. Collins showed that the PMI reported by the National Association of Purchasing Managers in the United States can explain movements in economic activity and stock market performance [14]. Koenig used the PMI to assess the strength of the US

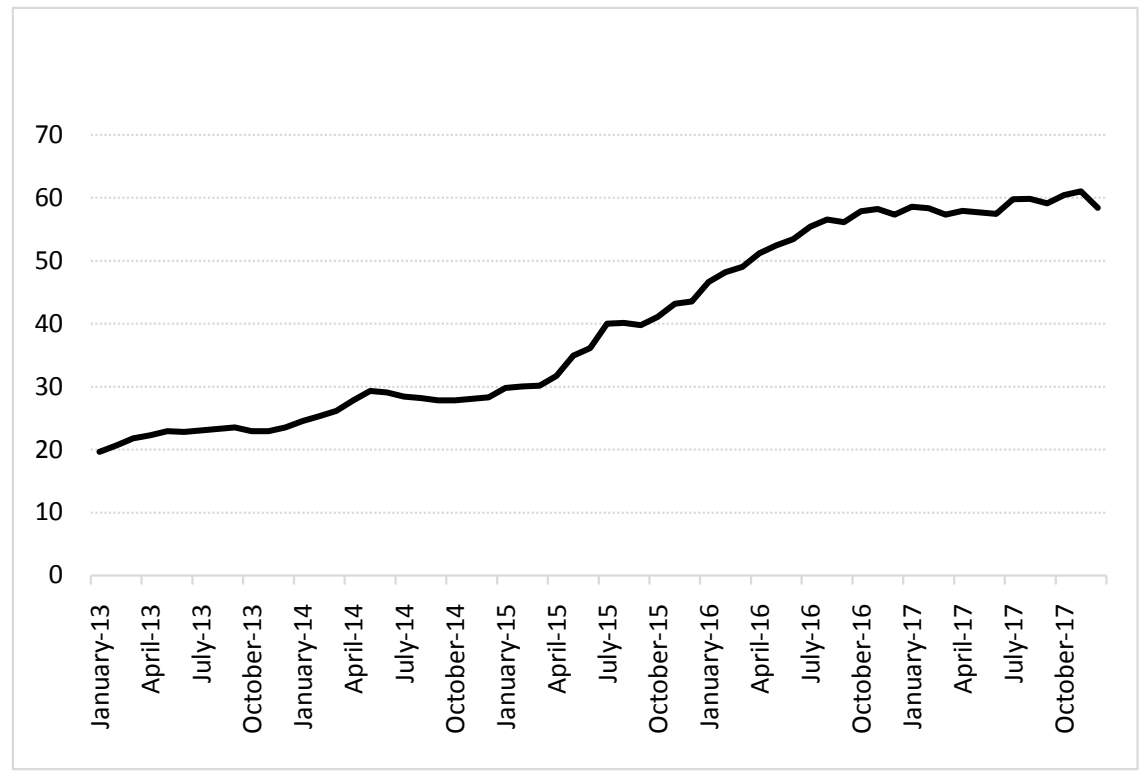

Figure 1. Scale of China's shadow banking, 2013-2017. 
economy and forecast the output of the economy [15]. The Chinese PMI is compiled by the China Federation of Logistics and Purchasing (CFLP) on the basis of data collected by the National Bureau of Statistics of China. The CFLP-PMI is constructed from a sample of 700 manufacturing firms throughout China. A growing number of studies investigating China's economy are employing the CFLP-PMI as a crucial indicator reflecting market confidence. Giannone, Agrippino, and Modugno used the CFLP-PMI to forecast the real gross domestic product of China [16]. Gui and Li used the PMI and Producer price index to analyze how confidence affects price level [17]. The PMI data for China are plotted in Figure 2.

\subsection{Data Description}

The key data selected for analysis were the scale of the shadow banking system, total loans of financial institutions, Shanghai Interbank Offered Rate (1-month-weighted mean), and PMI. Descriptions of each data type are presented in Table 1 and the summary statistics of the main variables are detailed in Table $2^{1}$.

The data were adjusted using the X-11 seasonal adjustment method and the first order difference was obtained by calculating the logarithm. The categories of data were renamed dlnsb_sa, dlnloan_sa, dlnrate_sa, and dlnpmi_sa.

After adjustment, all data passed the augmented Dickey-Fuller test as stationery time-series data. The results of the test are displayed in Table 3.

\subsection{Model Specification}

The SVAR model evaluates relationships between variables on the basis of vector autoregression, and thus has high power for explaining actual economic phenomena. The number of estimated parameters of the model is reduced by addition

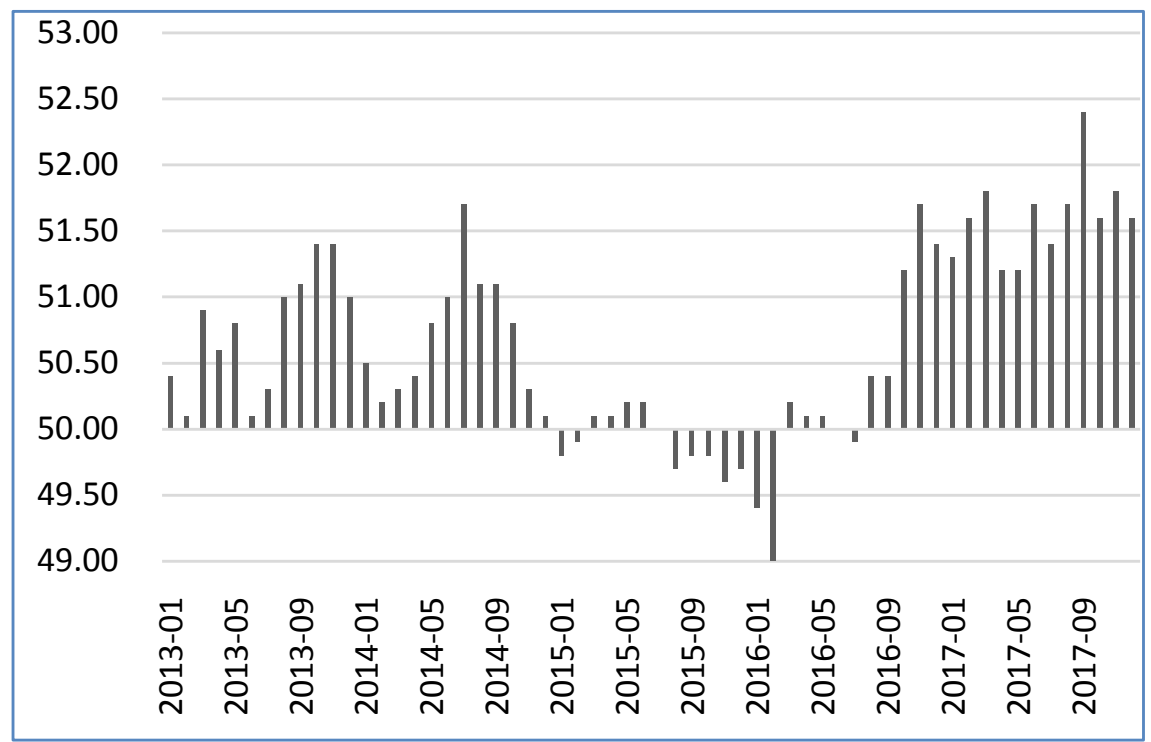

Figure 2. China's PMI, 2013-2017.

${ }^{1}$ There are no missing data. 
Table 1. Data sources and descriptions.

\begin{tabular}{|c|c|c|c|}
\hline Term & Meaning & Data Sources & Description \\
\hline M2 & Money and Quasimoney & People's Bank of China & \\
\hline DGB & $\begin{array}{l}\text { Deposits of Government in } \\
\text { Commercial Banks }\end{array}$ & People's Bank of China & \\
\hline DGC & $\begin{array}{c}\text { Deposits of Government in } \\
\text { the Central Bank }\end{array}$ & People's Bank of China & \\
\hline TBB & $\begin{array}{l}\text { Treasury Bonds Hold by } \\
\text { Commercial Banks }\end{array}$ & $\begin{array}{c}\text { China Central Depository \& } \\
\text { Clearing Co., Ltd }\end{array}$ & \\
\hline TBC & $\begin{array}{c}\text { Treasury Bonds Hold by the } \\
\text { Central Bank }\end{array}$ & People's Bank of China & \\
\hline SB & $\begin{array}{l}\text { Net Assets of Total Banking } \\
\text { Financial Institutions }\end{array}$ & $\begin{array}{c}\text { China Banking Regulatory } \\
\text { Commission }\end{array}$ & As described in Section 2 \\
\hline FM & $\begin{array}{l}\text { Off-Balance-Sheet Wealth } \\
\text { Management Products }\end{array}$ & $\begin{array}{c}\text { China Central Depository \& } \\
\text { Clearing Co., Ltd }\end{array}$ & \\
\hline $\mathrm{L}$ & Loans & People's Bank of China & \\
\hline $\mathrm{FE}$ & $\begin{array}{l}\text { The Funds Outstanding for } \\
\text { Foreign Exchange }\end{array}$ & People's Bank of China & \\
\hline EB & Corporate Bonds & $\begin{array}{c}\text { China Central Depository \& } \\
\text { Clearing Co., Ltd } \\
\text { Shanghai Clearing House }\end{array}$ & \\
\hline LOAN & $\begin{array}{l}\text { Total loans of financial } \\
\text { institutions }\end{array}$ & People's Bank of China & $\begin{array}{l}\text { Loans in Renminbi and } \\
\text { foreign currencies in all } \\
\text { categories of financial } \\
\text { institutions }\end{array}$ \\
\hline RATE & Interest rate & People's Bank of China & $\begin{array}{l}\text { Shanghai Interbank } \\
\text { Offered Rate } \\
\text { (1-month-weighted } \\
\text { mean) }\end{array}$ \\
\hline PMI & Confidence index & Wind Co., Ltd & $\begin{array}{l}\text { Purchasing managers' } \\
\text { index }\end{array}$ \\
\hline
\end{tabular}

Table 2. Descriptive statistics.

\begin{tabular}{cccccc}
\hline Variable & Max & Min & Mean & Std.Dev & Obs \\
\hline lnsb & 1.785741 & 1.29262 & 1.569524 & 0.164894 & 60 \\
lnloan & 2.079659 & 1.8067 & 1.947884 & 0.081772 & 60 \\
lnrate & 0.831998 & 0.419939 & 0.591136 & 0.103671 & 60 \\
lnpmi & 1.719331 & 1.690196 & 1.704591 & 0.006295 & 60 \\
\hline
\end{tabular}

Table 3. Results of augmented Dickey-Fuller Test.

\begin{tabular}{ccccc}
\hline & $(\mathrm{C}, \mathrm{T}, \mathrm{L})$ & ADF statistic & $\begin{array}{c}1 \% \text { significance } \\
\text { level/critical value }\end{array}$ & P-value \\
\hline dlnsb_sa & $(\mathrm{c}, 0,0)$ & -9.764687 & -3.476805 & 0.0000 \\
dlnloan_sa & $(\mathrm{c}, 0,2)$ & -3.483754 & -3.477487 & 0.0098 \\
dlnrate_sa & $(\mathrm{c}, 0,0)$ & -12.95342 & -3.476805 & 0.0000 \\
dlnpmi_sa & $(\mathrm{c}, 0,1)$ & -10.03948 & -3.477144 & 0.0000 \\
\hline
\end{tabular}

Note: C, T, and L denote the constant term, time trend term, and lag, respectively. The lag order is determined using the Akaike information criterion. 
of structural constraints. SVAR is generally accepted as appropriate for analyzing interactions between time series. Therefore, this study used the SVAR model to analyze the interrelationships between shadow banking, commercial bank loans, interest rates, and market confidence. According to the Akaike information criterion, a lag of 2 was used in the model, represented as follows:

$$
y_{t}=\Gamma_{t-1} y_{t-1}+\Gamma_{t-2} y_{t-2}+u_{t} .
$$

The vector $y_{t}$ is

$$
y_{t}=\left[\begin{array}{l}
d \text { ln rate_sa } \\
d \ln \text { loan_sa }{ }_{t} \\
d \ln \mathrm{sb}_{-} \mathrm{sa}_{t} \\
\ln \mathrm{pmi}_{t} \mathrm{sa}_{t}
\end{array}\right]
$$

The general "AB-Model" form was used and the Cholesky decomposition method was employed, where matrix $A$ is a lower triangular matrix and matrix $B$ is a diagonal matrix; that is,

$$
A=\left[\begin{array}{cccc}
1 & 0 & 0 & 0 \\
\cdot & 1 & 0 & 0 \\
. & . & 1 & 0 \\
. & . & . & 1
\end{array}\right] B=\left[\begin{array}{cccc}
. & 0 & 0 & 0 \\
0 & . & 0 & 0 \\
0 & 0 & . & 0 \\
0 & 0 & 0 & .
\end{array}\right]
$$

\section{Results and Analysis}

The effects of rising interest rates on the lending scale of commercial banks and scale of shadow banking are illustrated in Figure 3. The left-hand plot depicts the change with respect to commercial banks' loan issuances, whereas the right-hand plot depicts the change with respect to loans issued through shadow banking.

As indicated by the model results, the scale of shadow banking was immediately narrowed by a higher interest rate; this indicated that monetary policy tightening had a considerable effect on shadow banking and compressed it. This was because the funds employed in shadow banking mainly originated from commercial banks; thus, increasing interest rates for commercial banks led to a rising cost of funds in the shadow banking system. However, approximately six periods after the tightening of monetary policy, the trend in the scale of shadow banking had reversed, with shadow banking becoming more prevalent. This was
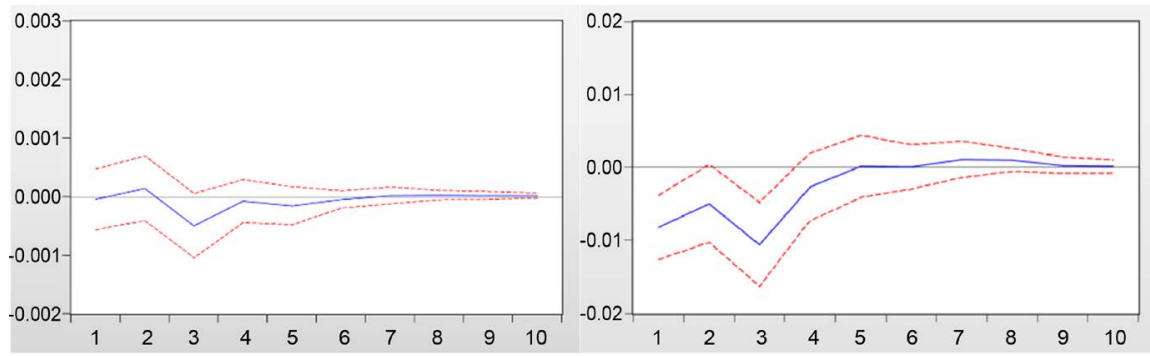

Figure 3. Responses to monetary policies of commercial banks and shadow banking. 
because the tightening of monetary policy increased the urgency of the demand for money in the market, particularly among enterprises unable to borrow from commercial banks and reliant on shadow banking financing. The austerity policy and rigid credit demand of the market fueled the long-term growth of shadow banking in China.

The influence of monetary policy tightening on commercial banks was initially positive; this seems to be contrary to the common sense that rising interest rates lead to a decreasing loan scale because the cost of credit increases. This result suggested that a rising interest rate is a signal of policy tightening that inevitably results in tightening of the overall credit environment, thereby blocking the shadow banking channel. Commercial banks reduced the availability of liquidity for shadow banking, and enterprises needed to resort to traditional loan services. Thus, in the short term, the loan scale for commercial banks increased slightly in response to increasing interest rates. However, this increase was shortlived and the scale of loans declined considerably after a few periods.

These processes demonstrate that shadow banking in China is somewhat dependent on commercial banks and monetary policy often indirectly affects the shadow banking system through commercial banks.

The effects of a confidence shock on the lending scale of commercial banks and scale of shadow banking is displayed in Figure 4. The left-hand plot depicts how increasing confidence affected commercial banks, whereas the right-hand plot depicts the effect on shadow banking in China.

The effect of the PMI differed from the commonsensical adage that increasing confidence leads to an increasing loan scale. The increase in confidence exerted no strong effect on the lending scale of commercial banks or shadow banking in the early period. Over the subsequent few periods, commercial banks and shadow banking began to reduce the size of loans and shadow banking were more volatile and more strongly affected than commercial banks.

The aforementioned phenomenon indicates the effect of confidence on credit transmission channels, which constitutes the feedback mechanism of monetary authorities to market prosperity. As illustrated in Figure 5, interest rates increased rapidly as the PMI rose because monetary authorities tend to exit easy monetary policies and increase interest rates when confidence improves. Xiaochuan Zhou, former president of the People's Bank of China, concluded that

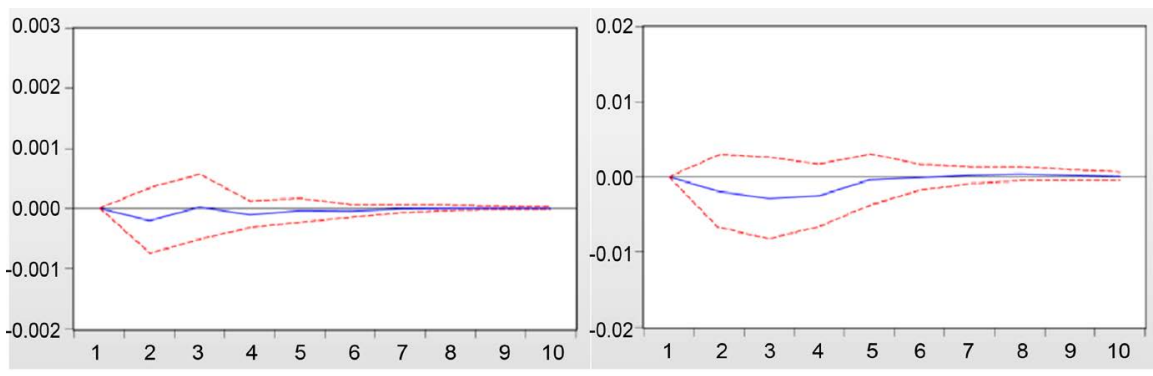

Figure 4. Responses of commercial banks and shadow banking to a confidence shock. 


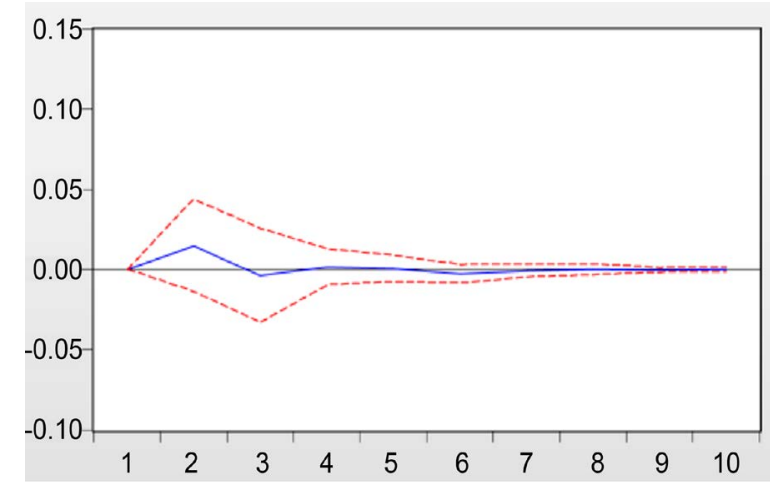

Figure 5. Response to a confidence shock of interest rate increase.

China's economy had had a tendency to overheat in the preceding few decades and indicated that preventing inflation and overheating was the top priority of monetary policies [18]. Consequently, China's monetary policy has been particularly sensitive to over optimism in the market.

As a result of the intervention of monetary authorities, the PMI increased, leading to higher interest rates that outweighed the credit demand induced by rising confidence. Therefore, after the PMI had increased, the scales of commercial banks and shadow banking were restricted; however, shadow banking was more sensitive to market shocks, and thus volatility was further increased.

\section{Conclusions}

On the basis of measurement of China's shadow banking system, this study estimated the effects of monetary policy and a confidence shock on the commercial and shadow lending sectors. We discovered the following key findings.

1) China's shadow banking has had strong links to commercial banks; however, compared with commercial banks, shadow banks were more strongly affected by monetary policy. When policies are tightened, the scale of shadow banking tends to decrease, whereas commercial banks have a substitution effect on shadow banking. This phenomenon led to major uncontrollability in the market that exacerbated the vulnerability of the financial system.

2) The effect of market confidence on the economy was achieved through the transmission of monetary policy. When market sentiment was favorable, monetary authorities tended to stop easing policies. This led to a widespread decrease in the scale of shadow banking that prevented economic overheating but exacerbated market volatility because of a certain degree of overreaction of the shadow banking system to monetary policy. This phenomenon occurred because of China's policy logic and the state of the Chinese economy.

The emergence of shadow banking has altered the traditional economic and financial structures, resulting in ineffective application of traditional theories and policies. Therefore, economic analysis and policy formulation are necessary. The policy implications are that strengthening oversight to move the shadow banking system to within the ambit of regulation is a worthwhile objective, and 
monetary policy should consider the responses of shadow banking.

\section{Conflicts of Interest}

The author declares no conflicts of interest regarding the publication of this paper.

\section{References}

[1] Adrian, T. and Shin, H.S. (2009) The Shadow Banking System: Implications for Financial Regulation. FRB of New York Staff Report No. 382.

http://dx.doi.org/10.2139/ssrn.1441324

[2] Gorton, G. and Metrick, A. (2012) Getting Up to Speed on the Financial Crisis: A One-Weekend-Reader's Guide. Jo urnal of Economic Literature, 50, 128-150. https://doi.org/10.1257/jel.50.1.128

[3] Pozsar, Z., Adrian, T., Ashcraft, A. and Boesky, H. (2010) Shadow Banking. New York, 458, 3-9. https://doi.org/10.2139/ssrn.1645337

[4] Wang, H., Wang, H., Wang, L. and Zhou, H. (2015) Shadow Banking: China's Dual-Track Interest Rate Liberalization.

https://ssrn.com/abstract=2606081 or http://dx.doi.org/10.2139/ssrn.2606081

[5] Elliott, D., Kroeber, A. and Qiao, Y. (2015) Shadow Banking in China: A Primer. Economic Studies at Brookings, 3, 1-7.

[6] Elliott, D.J., Kroeber, A.R. and Yu, Q. (2015) Shadow Banking in China: A Primer. General Information, 13.

https://www.brookings.edu/wp-content/uploads/2016/06/shadow_banking_china_e lliott_kroeber_yu.pdf

[7] Zhu, X. (2017) The Varying Shadow of China's Banking System. Working Paper.

[8] Ehlers, T., Kong, S. and Zhu, F. (2018) Mapping Shadow Banking in China: Structure and Dynamics. https://papers.ssrn.com/sol3/papers.cfm?abstract_id=3122350

[9] Verona, F., Martins, M.M.F. and Drumond, I. (2013) (Un)anticipated Monetary Policy in a DSGE Model with a Shadow Banking System. Bank of Finland Research Discussion Paper 4/2013. https://doi.org/10.2139/ssrn.2256278

[10] Funke, M., Mihaylovski, P. and Zhu, H. (2015) Monetary Policy Transmission in China: A DSGE Model with Parallel Shadow Banking and Interest Rate Control. BOFIT Discussion Paper No. 9/2015. https://ssrn.com/abstract=2580241 or http://dx.doi.org/10.2139/ssrn.2580241

[11] Allen, F., Qian, Y., Tu, G. and Yu, F. (2018) Entrusted Loans: A Close Look at China's Shadow Banking System. CEPR Discussion Paper No. DP12864. https://ssrn.com/abstract=3163517

[12] Chen, K., Ren, J. and Zha, T. (2017) The Nexus of Monetary Policy and Shadow Banking in China. American Economic Review, 108, 3891-3936.

[13] Sun, G. and Jia, J. (2015) Defining China's Shadow Banking and Assessing Its Scale: Seen in Terms of the Creation of Credit Money. China's Social Science, 92-110. (In Chinese)

[14] Collins, D. (2001) The Relationship between Business Confidence Surveys and Stock Market Performance. Investment Analysts Journal, 30, 9-17. https://doi.org/10.1080/10293523.2001.11082428

[15] Koenig, E.F. (2002) Using the Purchasing Managers' Index to Assess the Economy's Strength and the Likely Direction of Monetary Policy. Federal Reserve Bank of Dal- 
las, Economic and Financial Policy Review, 1, 1-14.

[16] Giannone, D., Agrippino, S.M. and Modugno, M. (2013) Nowcasting China Real GDP. Mimeo.

[17] Gui, W. and Li, Q. (2017) Structure Analysis and Transmission Mechanism of the Relationship between PMI and PPI Based on EEMD-JADE. The Journal of Quantitative \& Technical Economics, No. 4, 110-128. (In Chinese)

[18] Zhou, X.C. and Yi, G. (2012) China's Monetary Policy since the Year 2000 [Video File].

https://www.imf.org/external/AM/2012/mmedia/view.aspx?vid=1899411597001 